\title{
Characterization of Thermal Activated Fly Ash Adsorbent by Studying the Effect of Temperature
}

\author{
Aida Syarif ${ }^{1, *}$ Rusdianasari $^{1}$ M.Yerizam ${ }^{1}$ Sayhirmanyusi ${ }^{1}$ \\ ${ }^{I}$ State of Polytechnic Sriwijaya, Departement Chemical Engineering,Program Study Magister of Renewable Energi \\ *Corresponding author. Email: aida_s@polsri.ac.id
}

\begin{abstract}
Fly ash is a solid waste resulting from the use of coal as an energy resource. The potential for fly ash presence in Indonesia is considerable with increased coal consumption where the potential availability of coal ash is $10 \%$ of total coal consumption, with $80 \%$ details being fly ash. The increase in energy needs in Indonesia will have an impact on the increasing need for coal. Coal production in Indonesia in 2015 amounted to 461 million tons, by 2020 targeted coal production of 550 million tons (ESDM 2020). The potential for coal as an energy resource provides opportunities for the potential presence of fly ash. The chemical composition of fly ash coal ash consists of compounds $\mathrm{SiO} 2, \mathrm{CaO}, \mathrm{MgO}$. From the chemical composition contained in this fly ash, researchers studied the manufacture of fly ash as the raw material of adsorbents with methods thermal activated. In this study the parameters analyzed are the effect of activation temperature and length of time. From the results of the study, the temperature and activation time affects the characteristics of adsorbent from coal ash it can be seen the number of iodine increases in line with the increase in temperature, namely at a temperature $250^{\circ} \mathrm{C}$ and $350^{\circ} \mathrm{C}$ iodine number are $635 \mathrm{mg} / \mathrm{Kg}$ and $930 \mathrm{mg} / \mathrm{Kg}$.
\end{abstract}

Keywords: Fly ash, Activation, Temperature

\section{INTRODUCTION}

The increasing energy needs in Indonesia will be in line with the increasing needs of energy resources. The need for energy in Indonesia is currently estimated at $1,050.3$ million barrels of oil equivalent and $50 \%$ of it comes from imported fuels (Permana et al, 2010). In line with the plan to build a $35,000 \mathrm{MW}$ or $35 \mathrm{GW}$ power plant, both inside and outside java island, it will provide an important problem to the environment of the energy industry that uses coal fuel. The existence of coal ash as a result of the use of coal. The resulting solid waste will increase significantly and increase if not utilized.

Coal ash produced from pltu is categorized as fly ash and bottom ash with a composition of more than $80 \%$ is fly ash and $20 \%$ bottom ash.

The utilization of coal ash has been widely done research, soil construction materials in swamp water [1], as adsorbenes in the processing of $\mathrm{Cu} 2+[2]$ metals, such as acidic soil neutralization in mines

In this study will be carried out the utilization of coal ash with thermal activation process in the manufacture of ab coal into adsorbens.

\subsection{Coal Ash}

Currently, coal use among the industry is increasing, because in addition to relatively cheap prices also the price of oil fuels for the industry tends to rise. The use of coal as a substitute energy source for fuel, on the one hand is very profitable but on the other hand causing problems, namely coal ash which is a by-way result of burning coal. From a certain amount of coal use will be produced coal ash about $2-10 \%$ (depending on the type of coal, low calory or hight calory).

\subsection{Fly Ash}

According to SNI 03-6414-2002 the defines of coal fly ash is coal-burning waste in steam power plant furnaces that are smooth, round and pozolanic Fly ash is a material that has a fine grain size, grayish color and obtained from coal burning results. In essence fly ash contains chemical elements such as silica ( $\mathrm{SiO} 2)$, alumina (Al2O3), fero oxide ( $\mathrm{Fe} 2 \mathrm{O} 3$ ) and calcium oxide $(\mathrm{CaO})$, also containing other additional elements namely magnesium oxide $(\mathrm{MgO})$, titanium oxide $(\mathrm{TiO} 2)$, alkaline ( $\mathrm{Na} 2 \mathrm{O}$ and $\mathrm{K} 2 \mathrm{O}$ ), sulfur trioxide (SO3), pospor oxide (P2O5) and carbon [4] 


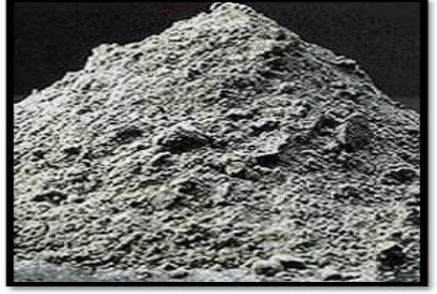

Figure 1. Fly Ash [4]

\subsection{Physical and Chemical Characteristics Fly Ash}

According to ACI Committee 226, it is explaine thatfly ash has characteristics in table 1

Table 1. Physical and Chemical Characteristic Fly Ash.

\begin{tabular}{|c|c|}
\hline Parameters & Quality \\
\hline Size & Pass of Sieving no.325 (45mili \\
Specific gravity & micron) $5-27 \%$ \\
Colours & $2,15-2,6$ \\
Silica dan & $\mathrm{Abu}-$ abu kehitaman \\
aluminium & $80 \%$ berbentuk amorf \\
Density & 2,23 gr/cm \\
Water conten & $4 \%$ \\
Composition mind & $\alpha-$ kuarsa dn mullite \\
ofmineral & $58,75 \%$ \\
$\mathrm{SiO}_{2}$ & $25,82 \%$ \\
$\mathrm{Al}_{2} \mathrm{O}_{3}$ & $5,30 \%$ \\
$\mathrm{Fe}_{2} \mathrm{O}_{3}$ & $4,66 \%$ \\
$\mathrm{CaO}^{3} \%$ & $1,36 \%$ \\
$\mathrm{alkali}_{\mathrm{MgO}}$ & $3,30 \%$ \\
$\mathrm{etc}$ & $\mathrm{Cu}, \mathrm{Pb}, \mathrm{Zn}, \mathrm{Cd}, \mathrm{Cr}$ \\
\hline
\end{tabular}

Source: ACI Commitee

\subsection{Activated of Coal Ash \\ 1.4.1 Physical Activation of Ash Coal}

The ability of fly ash adsorption can be improved through the process of carbonization and activation, carbonization is a thermal treatment at a temperature of $<700 \mathrm{oC}$ to eliminate volatile (noncarbon) compounds and encourage the form of pore structures with relatively small amounts and sizes [6] Activation is done to expand the size and volume of pores and form new pores. Physical activation (thermal activation) is performed by gasification at tempetarur $800-1000{ }^{\circ} \mathrm{C}$ with gases such as $\mathrm{CO}$ or steam.

\subsubsection{Chemical Activation of Ash Coal}

Sulfuric acid is a highly corrosive and viscous liquid-shaped slah stu, which is widely used in the industry. Pure sulfuric acid, which is not diluted, cannot be found naturally due to its hygroscopic properties. Sulfuric acid is formed naturally through oxidation of sulfide minerals. Sulphuric acid vapor is very irritative to the respiratory tract. Sulfuric acid as well as nitric acid is a powerful oxidizer. This strong acid is often the case that nitric acid is a powerful oxidizer. This strong acid is often used if it will analyze minerals from organic matter. Organic materials (skin included in it) will decompose into constituents such as $\mathrm{C}, \mathrm{H}, \mathrm{O}, \mathrm{N}, \mathrm{PB}$ and other minerals. Sulfuric acid can dissolve with water by all comparisons, and has a melting point of $10.31 \mathrm{oC}$ and a boiling point at $336.85 \mathrm{oC}$.

Before fly ash is used in the adsorption process, fly ash is first activated using sulfuric acid. In this study, sulfuric acid was used as an activator because it has a greater number of $\mathrm{H}+$ ions than other acids, and has hygroscopic properties that can absorb the water content found in fly ash. In addition, the activation purpose of the acid contact is to convert the cations contained in coal fly ash into $\mathrm{H}+$ ions and release $\mathrm{Al}$, $\mathrm{Fe}, \mathrm{Mg}$, and other cations (containing soil alkaline elements) from the structure lattice, thus physically the coal fly ash becomes more pore-specific surface area and its active site also increase.

During the activation process, the adsorbent surface and covering the active site from adsorbors can be eliminated by dissolving with sulfuric acid so that the adsorbent frame work has a wide area, and the active site also increases as the hidden site becomes open and will likely also bring up new active sites due to dissolving reactions. Increased pore-specific surface area and active site will improve the capabilities of its adsorption [4]. In addition, there is also a process of dealuminasi, namely the process of releasing Allumina from fly ash, which is presented in the following equations:

$$
\left(\mathrm{Al}_{4}\right)\left(\mathrm{Si}_{8}\right) \mathrm{O}_{20}(\mathrm{OH})_{4}+3 \mathrm{H}^{+} \longrightarrow\left(\mathrm{Al}_{3}\right)\left(\mathrm{Si}_{8}\right) \mathrm{O}_{20}(\mathrm{OH})_{2}+\mathrm{Al}^{3+}
$$$$
+2 \mathrm{H}_{2} \mathrm{O}
$$

$$
\begin{aligned}
& \left(\mathrm{Al}_{4}\right)\left(\mathrm{Si}_{8}\right) \mathrm{O}_{20}(\mathrm{OH})_{4}+6 \mathrm{H}^{+} \longrightarrow\left(\mathrm{Al}_{2}\right)\left(\mathrm{Si}_{8}\right) \mathrm{O}_{20}(\mathrm{OH})_{2} \\
& 2 \mathrm{Al}^{3+}+4 \mathrm{H}_{2} \mathrm{O}(2)
\end{aligned}
$$

The reaction states that al ions move from the structure, together with hydroxide clusters. The remaining $\mathrm{Al}$ atoms are still coordinated in a tetrahedral cluster with four oxygen atoms remaining. Changes from octahedral to tetrahedral clusters make the crystal lattice negatively charged on the crystal surface, so that it can be neutralized by hydrogen ions. In the next activation process there is a more release process. The reaction equation can be written as follows:

$$
\begin{gathered}
\left.\mathrm{Al}_{4}\right)\left(\mathrm{Si}_{8}\right) \mathrm{O}_{20}(\mathrm{OH})_{4}+3 \mathrm{H}^{+} \longrightarrow \mathrm{Al}^{3+}+(\mathrm{Al})\left(\mathrm{Si}_{8} \mathrm{H}_{4}\right) \mathrm{O}_{20} \\
\left(\mathrm{Al}_{4}\right)\left(\mathrm{Si}_{8}\right) \mathrm{O}_{20}(\mathrm{OH})_{4}+6 \mathrm{H}^{+} \longrightarrow \mathrm{Al}^{3+}+\left(\mathrm{Si}_{8} \mathrm{H}_{8}\right) \mathrm{O}_{20}
\end{gathered}
$$

\subsection{Scanning Elektron Microscopy (SEM)}

Scanning Elektron Microscopy (SEM) used for microstructure analysis and for conducting investigations related to the processes, properties, and characteristics of materials related to their micro structures. Scaning Electron Microscopy (SEM) scanning provides information related to topography, morphology, phase distribution, composition differences, crystal structure, crystal orientation, the absence of defects in microstructs and location defects in microstructs. The advantages of Electron Microscopy (SEM) scanning lie in the flexibility of testing with this method because the generator uses dual signals, an easy 
image formation process, a wide magnification range, and a very large depth field.

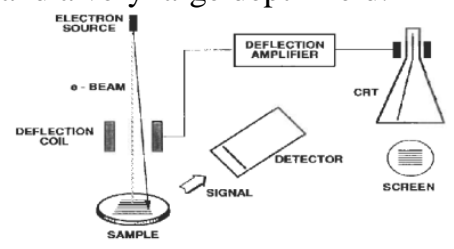

Figure 2. Instrument SEM

\section{METHODOLOGY OF RESEARCH}

Research is conducted with two stages. The first stage of the fly ash activation process. this stage as a stage of the process of creating adsorbent with thermal activation. The parameters performed in this process are activation temperature with variables $150,200,250,300$ and $300{ }^{\circ} \mathrm{C}$, while the activation time is 1 hour and 2 hours.

The second stage characterization of ash adsorbent through the testing of their chemical adsorbsi with Iodine Number test, being porosity test conducted by analysis using Electro Magnetic Scanning test.

\section{DISCUSSION}

\subsection{Chemical characterization of Activated Coal Ash}

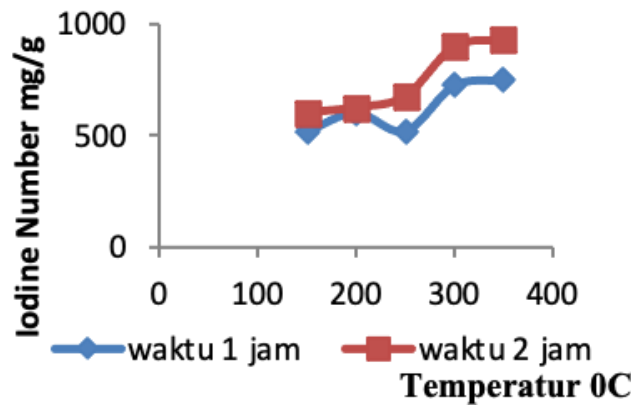

Figure 3. Graph of Iodine Number coal ash Activated

Effect of activation time on iodine number of activated coal ash. Figure 3 states the Garfik Iodine value of activated coal ash adsorbens with activation temperatures of $150,200,250,300$ and $350{ }^{\circ} \mathrm{C}$. from the graph can be observed that the increase in temperature and activation time affects the iodine number adsorbens. The highest iodine figure is at $350{ }^{\circ} \mathrm{C}$ and the activation time is 2 hours. This states the ability to absorbs from material adsorbens with significant temperature increases is due to the high temperature the factures of the chemical structure bonds that exist in fly ash due to the effect of warming on fly ash. With changes in the structure and compounds, the ability to absorb larger materials is matched by a large iodine number. The Iodine Number of adsorbens at $350^{\circ} \mathrm{C}$ and the activation time of 2 hours is $930 \mathrm{mg} / \mathrm{g}$. This states the ability of adsorbent to absorb solute amounting to $930 \mathrm{mg}$ per gram of adsorbent.

\subsection{Scanning Electro Magnetic (SEM) Characteristic}

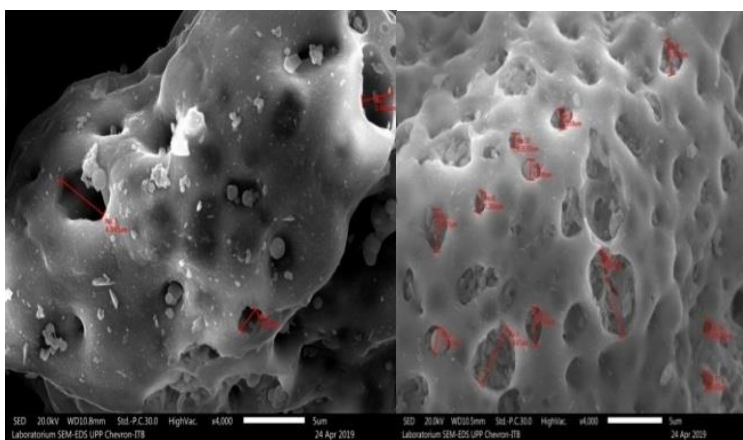

Figure 4. Result SEM surface Area from coal ash activated (a) temperature $250^{\circ} \mathrm{C}$, (b) temperature 350 ${ }^{0} \mathrm{C}$,

Figure 4 states the surface area of activated coal ash in $\mu \mathrm{m}$ size obtained by analysis using electron microscopy scanning tool with magnification $\mathrm{x}$ 4000. Before adsorbent are analyzed first dicoating. Figure $3 \mathrm{a}$. states that adsorbent with temperature activation of $2500 \mathrm{C}$ can be seen from the image that the number of pores on the surface is more than the previous image with a larger pore surface area and there are several pores in which there are pores. All pores are perfectly open with a larger pore area of $4,048 \mu$ mwith

Figure $3 \mathrm{~b}$. is a photo of an adsorben with a temperature of $350 \mathrm{oC}$. it can be seen from the image that the number of pores on the surface is more than the previous image with a larger pore surface area and there are some pores in which there are pores. A good pore that has depth and there is a pore cavity in it and all pores are perfectly open with a larger pore area of $5,4820 \mu \mathrm{m}$.

\section{CONCLUSION}

Based on the results of the research that has been done can be concluded that the characterization of adsorbent coal ash with thermal activation can be concluded:

1. Coal ash can be used as adsorbent material through thermal activation process.

2. Temperature activation affects adsorbent quality by being declared from iodine number.

3. The largest Iodine Number can be at activation temperature $3500 \mathrm{C}$ with Iodine Value $930 \mathrm{mg} / \mathrm{g}$.

4. The length of time activation affects iodine number adsorbent long time 2 hours for each activation temperature gives an increase in iodine number value. Iodine the largest number at 2 hours.

5. Sem characterization of adsorbent states temperature affects the face area of the adsorbent, the largest face area in this study is at temperature $3500 \mathrm{C}$ with a face area of 5 , 


\section{REFERENCES}

[1] Misbakhul Munir et al, 2008" Use of Coal Ash (fly Ash) for Hollow Blok, Universitas Diponogoro Semarang.

[2] Akmad Zakaria et al, 2012 "Utilization of flying ash physics activation in the absorption of Metal $\mathrm{Cu} 2+"$, Proceedings of Ilimiah Meeting of Materials Science, Serpong

[3] Aida,S dkk 2016"characteristic composite result between waste Rock and CoalAsh in Prevention Effortts Forming Acid Mine Drainage" Proceeding Forum in Research and Tecnology (FIRST).
Politecnic State of Sriwijaya.

[4] Suci, FC.. 2012 "Utilization of Coal Kite Ash (Fly Ash) Activated As Adsorben Ion Metal $\mathrm{Pb}+$. Surabaya. Faculty of Science and Technology Faculty of Chemistry, SriwijayaUniversity.

[5] Evika. 2011 "Use of Adsorbent Charcoal Active Coconut Shell In Refining Oil Used Fry. Sultan Syarif Kasim State Islamic University of Riau Pekanbaru. $20: 23-24$.

[6] Rouquerol, F. (2014). Adsorption by Powders and Porous Solids: Principles, Methodology and Applications, $\quad$ Elsevier, Oxford. 